\title{
THE TRANSITION TO DEMOCRACY IN VICTORIAN ENGLAND
}

"The organization and the establishment of democracy in Christendom", de Tocqueville wrote in 1835 , "is the great political problem of the time." 1 Nowhere was the problem more urgent than in England, whose industrial towns were soon to be torn by intense class conflict. Yet England resolved the tensions of the I830's and 1840's, and went on to build a tough and supple political democracy in a massively undemocratic society.

How did England become a democracy? The question has received little explicit attention from historians. Implicit in most narrative accounts of Victorian politics, however, is an answer of this sort: in response to outside pressure Parliament passed the reform bills that gradually democratized a long established system of representative government. Although this interpretive formula is unexceptionable up to a point, it conveys the impression that England became a democracy primarily as a result of statutory changes in the electoral system, whereas in fact the historical process involved was a good deal more complex. This exploratory essay is intended as a preliminary inquiry into the nature of that process.

Extending the franchise to the working classes was the nub of the problem of democracy in England. As Disraeli remarked to Bright in March, 1867, "The Working Class Question is the real question, and that is the thing that demands to be settled." 2 The franchise issue was not exclusively political, however, but an expression of a much larger and more complicated problem of class relations. As a result of rapid industrialization, England in the middle third of the nineteenth century had to devise arrangements that would enable the middle and working classes of the industrial towns to live together peacefully on terms they

${ }^{1}$ Alexis de Tocqueville, Democracy in America, edited with an introduction by Henry Steele Commager (New York 1947), p. 216.

2 R. A. J. Walling, ed., The Diaries of John Bright (New York 1931), p. 297. 
considered just. Hence, in order to understand the transition to democracy in England, it is necessary to treat political developments as an integral part of a wider pattern of settlement and adjustment between the classes. Moreover, "becoming a democracy" required not merely the extension of the franchise, but the creation of new habits and attitudes governing political relations between the working classes and the rest of the community.

If these heuristic suggestions are valid, it becomes necessary to devote considerable attention to the mid-Victorian industrial towns, not only as sources of pressure for parliamentary reform, but also as centers of conflict and accommodation, where the middle and working classes negotiated the terms of their social and political relations. In the towns the contending classes found a modus vivendi that preserved the hegemony of the middle classes while satisfying the immediate aspirations of the workingmen. The working classes came to accept a well defined social role-co-operating with the bourgeoisie in an effort to achieve their allotted share of progress and improvement within the existing framework of power and status. In politics a parallel pattern of class relations emerged, as workingmen accepted the ideology and the leadership of middle-class Radicals in demanding household suffrage. On these terms the towns found a solution to the franchise issue.

These developments in the mid-Victorian towns influenced the transition to democracy in England in three distinct ways. First, the rapprochement between the middle and working classes removed the chief barrier to a substantial extension of the franchise, the fears and suspicions generated by the Chartist episode. Second, the parliamentary reform agitation in the towns forced the House of Commons to take action on the franchise issue. Third, in the towns there took place those readjustments in habits and attitudes that constituted the essence of the process of "becoming a democracy"; classes divided by a vast social gulf found ways of collaborating politically; in the towns was forged that consensus on fundamentals so necessary to the smooth functioning of a democratic polity. Moreover, the political evolution of the industrial towns in the $1850^{\prime}$ 's and $1860^{\prime}$ 's contributed directly to certain typically conservative features of English democracy in the late Victorian period: the ascendancy of liberal ideology among the working classes, working-class acceptance of middle-class political leadership, and the Lib-Labism of the aristocracy of labor.

This sequence of events did not unfold automatically as a result of the operation of predetermined historical forces. On the contrary, the most important single factor in the process - middle-class Radical espousal of household suffrage - violated the strict logic of mid- 
Victorian urban culture, which sanctioned at most a limited extension of the franchise to the "intelligent and respectable artisan". Only because the Radicals chose to ignore the inhibitions imposed by their social situation were they able to impart a distinctive form to the emergence of democracy in England - the combination of a fairly large dose of electoral equality with political patterns congenial to an inegalitarian society.

From this perspective I shall sketch two aspects of the transition to democracy in the industrial towns of the I 850's and I 860's: first, the cultural patterns that embodied a solution to the over-all problem of class relations; second, the political patterns that emerged in that cultural setting under the auspices of middle-class Radicalism.

A deep crisis in class relations engulfed the industrial towns of early Victorian England. An apparently irrepressible conflict between the middle and working classes gave rise to a series of turbulent agitations: the recurring struggle for shorter hours; the outburst of Owenite utopianism; the bitter battle against the new Poor Law; and the Chartist explosion. Toward the end of the I 840's the waning of the trade depression brought a relaxation of tension, but it did not remove the underlying problem of class relations. An uneasy truce prevailed.

The tensions of the I 840's finally disappeared when the bourgeoisie fashioned a way of life that won the allegiance of the working classes. In this enterprise the middle classes showed consummate skill in adapting old forms to new circumstances. To begin with, they were able to utilize attitudes of deference and acquiescence that persisted among the working classes despite the troubles of the Chartist era. In addition, the bourgeoisie could proceed within the framework of a fairly widespread consensus about traditional values: the capitalist ethic; the moral and intellectual values of the Christian and liberal raditions; the growing faith in progress and improvement. Finally, there already existed in early Victorian England the beginnings of a network of institutions devoted to the practical realization of these purposes. Building on these foundations, the middle classes introduced two innovations that made possible the remarkably stable and cohesive culture of the mid-Victorian industrial towns. First of all, they came to put a new and prominent emphasis on extending values to an ever larger segment of the population. In the second place, they sought to bring about the fullest working-class participation in the pursuit of socially approved goals. 
Middle-class initiative was essential to the effective functioning of this social system. The bourgeoisie took up the mission of "elevating the masses" with their wonted earnestness. This meant transmitting appropriate traits and habits to the upper strata of the working classes. The capitalist virtues of thrift and diligence - redefined in the gospel of work - were singled out for special attention. Morality and intelligence were to be fostered in a context of deference and respectability. To accomplish these ends existing institutions were expanded and new ones constructed. But workingmen were not to be merely passive recipients of charity. In keeping with the principle of self-help, they were to be admitted to a junior partnership in the joint enterprise of improvement and advancement. Assisted by their superiors, whose superiority they would continue to acknowledge, they would run their own institutions wherever possible.

Thus, mid-Victorian urban culture rested on a tacit agreement among the classes as to values and roles. All groups in the community were devoted to a common purpose: social, moral, and intellectual improvement. Within that framework, however, there would be considerable variation from class to class. The bourgeoisie would assist the working classes to advance themselves, but without in any way disturbing established power and status relations. Workingmen were to be encouraged to strive to achieve bourgeois values, but always in a form appropriate to their station.

The arrangements devised by the bourgeoisie were bound to attract an immediate and enthusiastic response from the aristocracy of labor. Even at the height of the Chartist upheaval the ideal of moral and intellectual improvement, for example, enjoyed an unchallenged prestige among many skilled artisans. William Lovett's National Association for Promoting the Political and Social Improvement of the People declared itself "in favour of establishing Public Halls and Schools for the people; in which their children may be properly educated and themselves mentally and morally improved." The seventh "object" of the Association anticipated one of the standard social pieties of the mid-Victorian towns: "To promote the education of the rising generation and the political and social improvement of the people by means of Schools, Lectures, Public Meetings, Discussions, Classes for Mutual Instruction, and Meetings for Rational Amusement after their hours of toil." 1 Similarly, the Friendly Societies and the new co-operatives of the I840's testified to the strength of the ideals of

${ }^{1}$ G. D. H. Cole and A. W. Filson, British Working Class Movements: Select Documents I789-1875 (London 195 I), p. 381 . 
thrift and self-help among the artisan classes. With the coming of prosperity at the end of the decade, the middle classes showed a growing disposition to play the part of benevolent patron in helping the working classes to help themselves along these lines.

On countless occasions representatives of the middle classes proclaimed their dedication to the task of elevating the masses. A speaker opened the industrial and art exhibition of a Salford Workingmen's Club with these familiar words: "These exhibitions ought not to be lightly skimmed over, for, if the people were to advance in the appreciation of what was great and good and noble, they must study such collections." The exhibition was designed to set before workingmen "higher types of thought and expression, so as to lead them by degrees to a keener appreciation of the beautiful." He included the usual homily: "Success in this matter, as in all others, required study, thought, reflection, practice, and observation. Thought must be perfected by work, and labour guided by thought." 1 Editorials exhorted the middle classes to play their part: "if the organizations which exist for the instruction of the wealthy can be extended to a different class, a perennial source of moral, industrial, and political improvement will have been opened." 2 Likewise, public baths deserved support, because they would "tend greatly to promote habits of cleanliness among the working classes, which are essential to their health and self-respect." ${ }^{3}$ By I 863 one observer could state as a fact the middle-class image of its role. The middle classes, he wrote, would "go to almost any length" to improve the material condition of the working classes. "Every kind of benevolent project finds, and for thirty years has always found, the heartiest sympathy and support." 4

In elevating the lower orders the bourgeoisie had in mind a particular type of working-class character - reasonable, respectable, deferential that was to be the end-product of their benevolent activity. This cultural ideal was summed up in an editorial in the Manchester Guardian in 1898 , in which the writer was expressing satisfaction with the moderation displayed by the working classes. He concluded that education had "made the lower classes more intelligent, more selfreliant, more energetic, has taught them to think more justly of their

1 Manchester Guardian, September 3, 1866. Cited hereafter as M.G.

2 Ibid., January 7,1859 .

3 Ibid., May 8, 1850.

4 S. Maccoby, English Radicalism I 853-1886 (London 1938), p. 82, quoting The National Review, April 1863. For a satiric description of the middle-class conception of its philanthropic role see the excerpt from Porcupine in Margaret B. Simey, Charitable Effort in Liverpool in the Nineteenth Century (Liverpool 1951), p. 56. 
fellow countrymen, to feel ashamed of their former prejudices, and to acknowledge that it rests with them and not with any Government to ameliorate their social condition." $\mathrm{He}$ noted that even in strikes "moderation and order are generally manifested in their proceedings, and there is a better appreciation of the laws that govern the rise and fall of wages." 1 This passage underlines the ideological function of mid-Victorian social values and roles, in preserving and justifying the wealth, power, and prestige of the middle classes. Every step taken to elevate the workingmen was expected to reinforce their acquiescence in the existing order. But the culture demanded that this acquiescence be completely voluntary, and not extorted by coercion. A Norwich minister noted that there had come about "a far better spirit between classes, and a sounder feeling of trust in the men, both as between themselves and as regards employers and the richer orders. As elsewhere there had been far greater personal intercourse between the labouring and higher classes of late years than formerly, which has tended to a more human feeling on both sides." 2 Smoothing class relations was almost a cultural obsession. The task of overcoming the effects of class differences required "delicacy and earnestness", and could be accomplished "only by perfect singleness of purpose and manliness of heart." 3

The sentimental language was peculiarly characteristic of midVictorian social sensibility. Living through the Indian summer of the Evangelical revival, the middle classes found a social outlet for their earnestness and piety. A wholesale transfer of religious emotion to secular objects took place in the middle years of the nineteenth century. Evangelicalism, however much secularized, was responsible for the highly moralistic coloration of prevailing social values. More than most societies the mid-Victorian towns found moral significance in every aspect of the life of the community. Invariably, however, cultural values were circumscribed within uncriticized presuppositions inherent in the social and power structure of the community.

Mid-Victorian social values took for granted the vast disparity in power and status between the working class and the rest of the community. The acceptance of these class relationships, ingrained in the custom and habit of centuries, entered into every facet of the

1 M.G., October I4, I858.

2 J. M. Ludlow and Lloyd Jones, Progress of the Working Class 1832-1867 (London I 867), P. 294.

${ }^{3}$ M.G., January 7,1859 . Samuel Smiles, sensitive to every nuance of mid-Victorian culture, also called for a greater sympathy between classes: "Thus only can the breath of society be sweetened and purified." Asa Briggs, Victorian People (London I 95 4), pp. I 42-3. 
culture. In the bald clarity of the law these social facts found their clearest expression. Employers and employees were not equal before the law. The "servant" who broke a contract with his "master" had committed a crime; the "master" who broke a contract with his "servant", however, could only be sued for damages." Likewise, common law hostility toward trade unions and their activity reflected not only the application of legal principles but also the traditional view of proper relations between masters and men. ${ }^{2}$

The workingmen were an inferior class, clearly set apart from their superiors. Clerygmen were reminded that "the broad line of demarcation which on week days separates the workman from his master" did not fade away on Sunday. "The labouring myriads... forming to themselves a world apart", would be uncomfortable with "persons of a higher grade." 3 It was virtually impossible for the classes to meet "on the common platform of their humanity." "As a result of these unalterable social facts, the middle classes could not avoid a condescending attitude toward "the lower orders". To patronize inferiors was simply one of the many habits instilled by the society into which they had been born. Likewise, it was habitual for workingmen to accept the claims of their superiors.

By the middle of the nineteenth century one segment of the working class found itself in a good position to play the new role that was expected of it within the traditional social framework - collaborating actively with superiors in the pursuit of approved objectives. During the I $850^{\circ}$ 's and I860's the skilled artisans established themselves firmly as an aristocracy of labor. ${ }^{5}$ The more complex technology of a maturing industrial economy had created new skills. In particular the growth of the metal industries led to "an immense reinforcement of the labour aristocracy". At the same time the handicrafts had held their own. The skilled artisans, intent on setting themselves even farther apart from the laboring masses, were especially responsive to the sort of leadership being provided by the mid-Victorian bourgeoisie. They operated the proliferating institutions devoted to selfimprovement and self-help.

${ }^{2}$ See D. Simon, Master and Servant, in: J. Saville ed., Democracy and the Labour Movement (London 1954).

${ }^{2}$ See R. Y. Hedges and A. Winterbottom, Legal History of Trade Unionism (London 1930), Chapter s.

${ }^{3}$ G. M. Young and W. D. Handcock eds., English Historical Documents I833-1874, p. 390, quoting the Census Report of 185 I-53 on Religious Worship.

4 M.G., January 7, 1859 .

5 See E. J. Hobsbawm, The Labour Aristocracy in 19th Century Britain, in: Saville, ed., Democracy and the Labour Movement. 
Intellectual improvement was the objective of a bewildering array of institutions: Sunday Schools, Ragged and Industrial Schools, National Schools, British Schools, Mechanics Institutes, Working Men's Colleges, Working Men's Reading Rooms, Mutual Improvement Societies, and libraries. ${ }^{1}$ Social roles varied as much as the institutions themselves. In some instances the initiative rested entirely with the middle class, which dispensed charity in the traditional manner; often the classes collaborated; sometimes the workingmen did the job all by themselves. In the Mechanics Institute at Newcastle a member of the middle class "acted as secretary, and was, indeed, the animating spirit of the organization." 2 In contrast, the Working Men's Club at Kendal originated with workingmen and was entirely managed by them. The four hundred members had a newsroom, library, class and lecture rooms, and a chess room. ${ }^{3}$ The Workingmen's Institution at Hartshill, Stoke-upon-Trent, possessed "a beautiful building, erected at the sole expense of Colin Minton Campbell, Esq., at a cost of some $£ 600 . " 4$ All these groups shared a common goal. In the familiar language of mid-Victorian culture, as expressed by an M.P. at the eighth annual soiree of the Accrington Mechanics' Institution, their aim was "the moral and intellectual advancement of the people." 5 The sort of character that these institutions were trying to develop was described in these terms by a workingman who was a Methodist lay preacher: "Who amongst the teeming masses of our artisan and labouring population are marked by staidness of character, forecast, and consequent prudence and thriftiness, and who show the greatest skill in their respective employments? They are the numbers who frequent the class rooms and lecture rooms of our lyceums and mechanics institutions - those who avail themselves of the scanty provisions of our evening schools." 6

1 See Richard D. Altick, The English Common Reader (Chicago I957); B. Simon, Studies in the History of Education, 1780-1870 (London 1960); F. Smith, A History of English Elementary Education, 1760-1902 (London 193I); H. F. Mathews, Methodism and the Education of the People, I791-185I (London I949); S. E. Maltby, Manchester and the Movement for National Elementary Education, I800-I870 (Manchester 19I8); M. Tylecote, The Mechanics' Institutes of Lancashire and Yorkshire before I 85 I (Manchester 1957); M. Arnold, Reports on Elementary Schools, 18 8 2-1882 (London 1910); for excellent descriptions of the educational situation in two different industrial areas, see Education Commission, Reports of the Assistant Commissioners Appointed to Inquire into the State of Popular Education in England, 1861 (London 1861), II, 175-242, on Rochdale and Bradford, and 245-301, on the Potteries and the Black Country.

2 E. R. Jones, The Life and Speeches of Joseph Cowen, M.P. (London n.d.), p. 96.

${ }^{3}$ M.G., March 24, I866.

4 Ibid., January 15, 1859 .

5 Tbid., January $x, 1859$.

- Ibid., May I, 1850. For an account of the mutual improvement societies and workingmen's clubs see Ludlow and Jones, op. cit., pp. $174^{-80}$. 
Another cluster of institutions was devoted primarily to encouraging "prudence and thriftiness": the friendly societies and co-operatives. ${ }^{1}$ They enabled skilled workers to make some provision for the contingencies ignored by the state, to practice capitalist virtues outside the profit system, and to invest whatever surplus remained after meeting subsistence needs. Poor law policy, of course, made thrift a necessity as well as a virtue, since improvidence ensured the swift loss of everything the artisan had been striving for. The workhouse stigma put an edge on the sort of homily delivered by an M.P. at the annual meeting of the Bury district of the National Order of Oddfellows in 1866: "He hoped that in the season of prosperity which was dawning upon them [the working classes] they would lay up for a time of adversity. He called upon all young men not connected with such a society to at once join one, and advised young ladies to look shy at any man who did not thus display an inclination to be provident." 2 The artisan did not really need to be reminded that he had to be provident, or else.

The immense apparatus of self-help tended to attach the artisan classes to the established order and contributed to a relaxation of the tensions of the early Victorian period. When a Norwich minister described the "change for the better" that had come about in the town since the days of "distrust of class against class and man against man," he cited the growth of the provident institutions: "The Cooperatives have had a large store, with branches, for eight or nine years, very successfully carried on... The societies of Odd Fellows are very large. Building Societies are successful, but I think mostly among the upper artisans and small shopkeepers, the average of low wages preventing the ordinary workman from using them." He noted also that "the Co-operatives and other clubs are reading far more than formerly, both books and papers." 3 It was characteristic of the interconnectedness of the various segments of mid-Victorian culture that the co-operative stores should not limit themselves to merchandising, but tried to do a great deal more, as in the North, for example: "They [co-operative stores] generally have their own buildings, which include commodious halls for the purposes of public meetings, lectures, concerts, tea-meetings and conversazioni, chiefly promoted by and for the members of the Society and their families." 4

${ }^{1}$ See J. M. Baernreither, English Associations of Working Men (London I 891); Ludlow and Jones, op. cit., ch. 2 ; G. D. H. Cole, A Short History of the British Working Class Movement (London 1948), pp. 1 \$2-68.

2 M.G., September 3, 1866.

${ }^{3}$ Ludlow and Jones, op. cit., pp. 29 I-2.

4 Jones, Joseph Cowen, pp. 96-7. 
The trade unions of the skilled artisans held a unique position in the institutional structure of the industrial towns. On the one hand, they were at odds with the prevailing patterns of the society, because they carried the threat of a shift in power relations between the classes and because they interfered with the right of the capitalist to dispose of the factors of production as he saw fit. In this respect, they constituted an important countervailing force in the community, limiting the dominance of the bourgeoisie. On the other hand, the New Model unions accepted the same values and presuppositions that defined the purposes of other institutions in the society. ${ }^{1}$ Their lines too came from the same script. The Manchester district division of the Amalgamated Society of Engineers, at its annual festival in I866, took pride in fact that in the last fifteen years "they had progressed in moral tone, in education, and in the method of conducting their disputes." They were proud that "they no longer relied on physical force, but on their own intelligence, and on the fact that they were recognized as a body having a right to meet and transact their own affairs." Nevertheless, their moderation did not restrain them from denouncing the employers association "from whom had emanated such documents as their society would be ashamed to issue." 2 Precisely because they accepted in good faith the ideals of the culture, the trade unionists were apt to be shocked when employers' actions violated the code.

The New Model trade unions were pre-eminently Victorian in their preoccupation with self-help. In return for fairly high dues they provided their members with a wide range of benefits covering sickness, unemployment, and death. Moreover, as representative midVictorian institutions, the trade unions did not think of themselves as devoted to exclusively utilitarian objectives. Like the Amalgamated Society of Carpenters and Joiners, they hoped that "by the establishment of libraries and listening to the voice of the lecturer on all subjects connected with our interests, we and our sons shall become respectful and respected, and make rapid progress in the onward march of reform." 3

1 See S. and B. Webb, The History of Trade Unionism (London 1920), pp. 180-232; G. D. H. Cole, A Short History of the British Working Class Movement (London I948), pp. I69-85; Asa Briggs, Victorian People (London 1954), ch. 7, The Age of Improvement (London, 1959), pp. 408-4Io; G. D. H. Cole has described the wide variation within the mid-Victorian trade union movement in Some Notes on British Trade Unionism in the Third Quarter of the Nineteenth Century, in: International Review for Social History, II, 1937 .

2 M.G., September 7, 1866.

${ }^{3}$ Briggs, Victorian People, p. 178. 
Among the varied institutions that touched the life of the industrial towns, church and chapel exerted a most pervasive influence. ${ }^{1}$ In one way or another, they reached all classes in the community, even those at the very bottom of the social scale. Town missions were designed for the unskilled laborers. A group of Manchester lurrymen, employed in stables operated by the goods department of a railway, received a good deal of attention. For eighteen months they were visited every Sunday morning by two of the city missionaries. The lurrymen responded in the manner expected of them: "They have been so well pleased with the advice and religious papers - about six thousand in number - which have been given them, that they were anxious to testify their grateful thanks for the persevering labours of those who had thus sought to do them good." At a tea party celebration in the Methodist Chapel, four of the men "gave short but clear statements of the benefit they themselves had derived as well as that which they had observed in others." A member of the middle classes described the practical value of bringing religion to the masses: "One gentleman from a merchant's warehouse bore the most gratifying testimony to the marked improvement in the language and conduct of the lurrymen in their daily work of delivering and collecting goods." 2 The Manchester Town Mission conducted this sort of missionary work on a large scale. In 1850 it employed fifty-two agents "who read the scriptures from house to house, converse with the inmates upon the truths of the gospel, and urge the importance of all attending places of public worship, and of parents sending their children to school." 3 Significantly, the Mission's report recorded $£^{200}$ in contributions from workingmen's district associations. The better-off workingmen were thus encouraged to take part in elevating their own social inferiors.

The skilled artisans were being assimilated into the religious community of the mid-Victorian cities on much the same terms that characterized their position in the society as a whole. They were welcomed into the congregations, chiefly of the Nonconformist denominations, with the understanding that they would continue to play a clearly defined deferential role. Class lines were firmly drawn. Even within a single church or chapel there developed "religious groups of different social levels that seemed incapable of merging.

${ }^{1}$ See E. R. Wickham, Church and People in an Industrial City (London 1957). Chapter 4 not only describes the religious situation in Sheffield between 1850 and 1900, but also notes the presence of similar patterns in other cities. See also K. S. Inglis, Churches and Working Classes in Nineteenth Century England, in: Historical Studies: Australia and New Zealand, VIII, No. 29, 1957.

2 M.G., January 5, 1859.

3 Ibid., April 27, 1850. 
Thus the Bible classes were distinct from the congregations, the frequenters of the Workmen's Mission would not go to the classes." 1 The workingmen had to put up with the sort of thing that irritated a Methodist lay preacher in Salford: "As a member and local preacher in the body, I move and have continual intercourse with my own order - operatives and artizans of intelligence - who complain to be so misrepresented. The fact is, our opinions are unascertained; we are never consulted." $2 \mathrm{He}$ complained that the Wesleyans were dominated by "the Plutocracy". In many instances "the indiscriminate poor" did not join a chapel at all, but preferred to attend services in the Church of England, "where they could probably worship with less inhibition than in a large predominantly middle-class chapel." 3 Many workingmen, including artisans, remained estranged from religious institutions. For the most part, however, the respectable workingman participated in religious life in the manner deemed appropriate to his station.

Religiously significant activity was not considered the exclusive province of church and chapel, however. Even so secular a figure as the Registrar of Friendly Societies could be described as "a minister of self-help to the whole of the industrious classes." 4 In justifying this analogy the speaker explained the "true moral unity" that could be discerned in the functions of the Registrar, who handled not only savings banks and benefit clubs, but also scientific and literary institutions devoted to mental improvement. The same "moral unity", reflecting a transfer of religious earnestness to interconnected secular values and institutions, was the most distinctive characteristic of mid-Victorian culture.

This unity was formally manifested in a standardized ritual. At tea parties, annual meetings, festivals, Christmas parties, exhibitions, and soirees the middle and working classes acted out their roles and affirmed the values of the community. The middle classes were benevolent and condescending, the working classes were grateful and respectful. Speaker after speaker intoned the litany of social, moral, and intellectual improvement. The reassuring ritual bespoke a society in equilibrium.

1 Wickham, Church and People, p. 159. For examples of the relationship between the working classes and religious institutions in Liverpool, Bradford, and Manchester see the evidence presented to the Select Committee of the House of Lords on Deficiency of Means of Spiritual Instruction, Parliamentary Papers, 1857-58, IX, pp. $382 \mathrm{f}$., 4 I $6 \mathrm{f}$., $448 \mathrm{f}$.

M.G., May 1, 1850.

Wickham, p. I4r.

4 Young and Handcock, op. cit., p. 315. 
There was one unsettled issue that threatened to disrupt this delicately balanced system, however.

\section{III}

The franchise issue could not readily be settled according to the standard formulas of mid-Victorian urban culture, because any substantial extension of the right to vote seemed likely to produce a major shift in the balance of power between the classes. Political equality ran against the grain of a highly stratified society. To the average merchant or manufacturer in 1850 it seemed the height of demagogic irresponsibility to suggest enfranchising a large segment of the ignorant and impoverished masses, since it was only reasonable to assume that such voters would immediately use their new power to hold the rich for ransom. When the Manchester Guardian denounced John Bright's "wild and mischievous doctrines" in 1858 , it was merely expressing the normal bourgeois fear of household suffrage. Yet workingmen were bound to demand the vote on grounds of principle and expediency. The Chartist crisis had dramatized the predicament that had to be resolved before England could begin to become a political democracy: Without strong pressure the propertied classes would not extend the franchise; but the stronger the pressure the more stubbornly they were bound to resist; and middle-class resistance was sure to provoke another explosion of the Chartist type.

England found a way out of this impasse largely as a result of the initiative of middle-class Radicals, whose efforts in behalf of household suffrage facilitated the transition to democracy. Despite the fears generated by Chartism, a vigorous middle-class Radical movement emerged in the industrial towns at a very early date. Throughout the I 850 's and I860's working-class advocates of parliamentary reform knew that they could count on growing middle-class support.

At the height of the last Chartist outburst, an influential group of free traders, led by George Wilson and Richard Cobden, announced the goal that middle-class Radicalism was to pursue for the next generation: "a union of the middle and working classes for the purpose of obtaining an extension of the suffrage, vote by ballot, equal electoral districts, and a reduction of taxation." 1 The House of Commons spokesman for the "New Movement" was Joseph Hume, who called for petitions in support of a household suffrage resolution that he proposed to introduce. The towns responded enthusiastically to the

1 M.G., May 3, I848; London Times, May I, I848. 
appeal of "Messrs. Cobden, Hume \& Co." ${ }^{1}$ Eearly in June the Times reported: "The Ultra-Liberals in the West Riding of Yorkshire, as in other parts of the kingdom, are making efforts to get up public meetings and pass resolutions" in favor of Hume's motion. ${ }^{2}$ By June 20 the House of Commons was deluged with petitions calling for household suffrage. ${ }^{3}$ No action was taken, however, and the agitation ended abruptly.

Although the New Reform Movement disappeared quickly, the attitudes and purposes that it expressed were to give life to middleclass Radicalism throughout the I850's and I860's. ${ }^{4}$ The major premise of the movement remained unchanged: the middle and working classes shared a common interest in wresting "reform" from the ruling aristocracy and its satellites. On that basis the Radicals were determined to forge an alliance between the classes that had been at odds for so long. Although the middle-class Radicals did not organize a continuous and sustained agitation, on three occasions they conducted large-scale campaigns for household suffrage.

The Parliamentary and Financial Reform Association organized the first of these campaigns between 1849 and 1852 . Branch societies were formed in a number of provincial cities, and several national conferences were held. ${ }^{5}$ The Association won a strong following among middle-class Radicals in the industrial North and claimed that its delegates included "some of the largest manufacturers and employers of labour in Lancashire and Yorkshire." "Even when the formation of a Tory government in February 18,2 seemed to threaten the revival of protectionism, the Association did not neglect household suffrage, but resolved that "this meeting believes radical Parliamentary Reform to be the great practical want of the day." 7 By 1853 the Association was inactive; in 1855 it was formally dissolved.

The next outburst of Radical activity in behalf of household suffrage came in 18,8-9 under the leadership of John Bright. When Bright called for a parliamentary reform agitation in his Birmingham

- M.G., May 3, 6, 17, 1848; London Times, June 1, 8, 21, I848; Illustrated London News, June 10, 24, 1848 .

${ }^{2}$ London Times, June 8,1848 .

3 Journal of the House of Commons, i 847-8, pp. $636-8$.

4 See Frances E. Gillespie, Labor and Politics in England (Durham 1927); S. Maccoby, English Radicalism, 1832-1852 (London 1935), and English Radicalism, 1853-1886 (London 1938).

${ }^{5}$ Gillespie, pp. 8 5-1 Io; Maccoby, English Radicalism I832-1852, pp. 314-315; Illustrated London News, January $12,1850$.

B M.G., December 6, I8 5 I.

7 Illustrated London News, March 6, 1852 ; M.G., March 6, I85 2. 
speech in October 1858 , the middle-class Radicals responded swiftly and energetically. By the end of the year the Manchester Guardian had to console itself with the thought that in Parliament Bright "will find how exceedingly small his party is, in proportion to the clamour it raises throughout the land." 1 The "clamour" continued unabated in January and February. In industrial towns large and small, reform associations sprang up; $;^{2}$ in Lancashire they joined together in a Lancashire Reformers Union, under the leadership of George Wilson and other former Leaguers; in Yorkshire local associations formed the West Riding Reform Association. ${ }^{3}$

The third and most ambitious of middle-class Radical undertakings preceded the passage of the second Reform Bill. The chief instrument of the movement was the National Reform Union, which presided over an extensive agitation between 1864 and 1867 . Although the Union was strongest in Lancashire and Yorkshire, its conferences attracted delegates from all over the country; in May 1865 over one hundred seventy towns were represented. ${ }^{4}$

What motives prompted so many able middle-class leaders to violate the normal inclinations of their class by advocating household suffrage? One unifying impulse behind the movement was a deep antipathy to the social and political hegemony of the landed classes. In carrying on what Cobden called "the great struggle against feudalism", the Radicals wanted every possible source of strength. All Radicals shared Cobden's annoyance that "we are the only nation where feudalism with its twin monopolies, landed and ecclesiastical, is still in power." 5 Even in the Universities there were men "who incline to democracy not on broad doctrinal grounds, but because they entertain a jealous dislike of a privileged order." " The class struggle between manufacturer and squire nourished the reformist impulses of middle-class Radicalism. Nonconformist resentment at Anglican privileges had the same effect. The desire for allies against the ruling Tory-Anglican oligarchy helped persuade many manufacturers and merchants to overcome their natural misgivings about

1 M.G., January I, 1859 .

${ }^{2}$ See M.G., January 1859 , passim; Gillespie, pp. $178 \mathrm{ff}$., describes Radical activity in the Midlands and the North.

${ }^{3}$ M.G., February 2, 1859; Gillespie, p. 154.

4 Gillespie, pp. 238-86; Maccoby, Radicalism 1853-1886, pp. 84-99; Cole and Filson, pp. 529-32; M.G., April 20, 1864, May 16, 17, 1865, November 20, 1866, February 20, 1867 .

5 T. W. Reid, Life of the Right Honourable William Edward Forster (London I888), I, p. 367 .

- Saturday Review, August 4, 1866. 
enfranchising working-class householders. Moreover, the evergrowing numbers of "respectable artisans" served to quell theoretical fears about "the masses".

As earnest Victorians many Radicals were also actuated by principle. They urged an extension of the franchise because justice demanded it. To be for reform was to be on the side of truth and morality. Characteristically, however, they also advocated household suffrage for realistic and conservative reasons. Bright argued that "great discontent and turbulence might arise if the workingmen felt that they are distrusted, that they are marked as inferiors, that they are a sort of pariahs [sic]." ${ }^{1}$ In a similar vein Cobden pointed out the advantages of middle-class leadership of the masses: "I can tell the manufacturers, capitalists, and men of station in this country, that whether it be time of crisis, or of tranquillity the only safety for them is to be at the head of the great mass of the people, and I therefore rejoice at the proceedings of this day, which have given us so favourable a prospect of that union, in which there is not only strength, but safety." 2

\section{IV}

In the course of the parliamentary reform agitation that unfolded under the leadership of middle-class Radicalism, the industrial towns settled the franchise question, found a mutually acceptable pattern of political relations between the middle and working classes, and completed the critical phase of the transition to democracy in England. By the time that Parliament took up the matter in earnest in 1866 the suffrage issue no longer was a source of social and political conflict as it had been twenty years before. An essential aspect of the process of becoming a democracy - the development of the necessary habits and attitudes on the part of all classes - had taken place before Parliament passed the Reform Act of 1867 . Moreover, the political and ideological forms that grew into existence in the 1850 's and 1860 's, firmly rooted in the structure of mid-Victorian urban culture, contributed significantly to the conservative character of English democracy in the last third of the nineteenth century.

The middle-class Radical campaigns for household suffrage ended the political isolation of the Chartists, accustomed the working classes to the leadership of their social superiors, vastly enhanced the prestige of liberal ideology, and brought the artisan elite into a close relationship with the left wing of the Liberal party. This train of events had

1 J. E. T. Rogers, ed., Speeches on Questions of Public Policy by John Bright, M.P. (London 1869), II, pp. I00-IOI.

2 M.G., December 6, 185 I. 
been set in motion even before the end of the I 840's by the Parliamentary and Financial Reform Association. On the surface, the Association appeared to have failed, since the militant Chartists remained hostile, the House of Commons refused to act, and the bulk of the middle classes remained aloof. Nevertheless, the movement toward political accommodation between the classes gathered momentum a few years later when the Radicals again took up the question of parliamentary reform.

The turning point in mid-Victorian urban politics came at the end of the I 850 's, during the formidable agitation led by John Bright, when workingmen joined forces with the middle-class Radicals. George Wilson noted with satisfaction that "there was no fear of the old game being played; ...the working classes were thoroughly prepared to accept the leadership of Mr. Bright." 1 Even Ernest Jones, who had led the Chartist opposition to the Parliamentary and Financial Reform Association a few years before, now conceded the need for political co-operation with the middle classes. ${ }^{2}$ Typical was the sort of event that took place at Middleton, where former Chartists voted to amalgamate with a middle-class group in order to organize the maximum support for Bright's campaign: "We may add that, considering there were collected on this occasion the most determined Chartists this neighbourhood was so noted for a few years ago, the utmost good temper and most liberal spirit was reciprocated betwixt themselves and that class so much railed against formerly, viz.: the middle class." 3

Another manifestation of the changed relations between workingmen and middle-class Radicals was the participation of non-electors' groups in the general election of 1859 , usually in behalf of Radical candidates. In various Yorkshire cities, for example, non-electors were active in the Radical cause. ${ }^{4}$ A Bradford group called on likeminded non-electors to persuade the electors to vote for the Radical candidate: "Urge upon the electors the justice and the necessity of voting for Salt... Tell them, by voting for Harris they politically ignore us as a class, thereby declaring themselves to be our worst and bitterest enemies." 5 In this way workingmen were being assimilated into the local political community even before they were enfranchised.

1 Ibid, February 2, 1859.

2 John Saville, Ernest Jones: Chartist (London 1952), pp. 62-76.

3 M.G., January 12, 1859.

4 W. L. Guttsman, The 1859 Election in Seven Yorkshire Cities, in: International Review of Social History, II (1957), Pt. 2.

5 Ibid., p. 253. 
The middle-class Radical campaign for the leadership of the working classes came to a climax in the I860's. The Radicals bestowed on the workingmen that full measure of flattery and attention which politicians usually reserve for voters. In their propaganda the National Reform Union and its member associations took pains to play up working-class participation and initiative in the parliamentary reform movement. Although the Union was not actually founded until i 864, the middle-class Radicals proudly traced its origin to a working-class group formed in 1860 , the Leeds Working Men's Parliamentary Reform Association. ${ }^{1}$ When a national conference met in Manchester to establish the Union, the organizers did all they could to emphasize the working-class sponsorship of the meeting. In fact, a group of Manchester workingmen was under the impression that they were electing delegates to "a national workingmen's conference". ${ }^{2}$ The Union continued to court the working class, and two years later received this rebuke from the Manchester Guardian: "The active spirits of the Reform Union have descended into a political alliance which, with all their faults, is unworthy of them, and are taking a leaf out of a book which they once had a right to despise. Since the time when the House of Commons was asked to receive a petition for the People's Charter..., the art of political vamping has not been practised on so imposing a scale as in the Radical demonstrations of the present parliamentary recess." 3 Through such "political vamping" the Radicals were bringing the working classes within the pale of the constitution even before the legislation of 1867 .

Despite the strictures of the Manchester Guardian, many workingmen felt that the Union was being unduly cautious in refusing to go beyond household suffrage. The Reform League, an independent workingclass organization devoted to manhood suffrage, was a powerful competitor for popular backing. But the Union managed to overcome even this obstacle. The Radicals were careful to avoid opposing manhood suffrage on principle, but insisted that only household suffrage had any chance of parliamentary acceptance in the near future. The argument was convincing. Eventually the Union even succeeded in achieving a working collaboration with the League. At Manchester in September 1866 , for example, the Union went out of its way to co-operate with its competitor. The northern department of the Reform League, a recent outgrowth of the Manchester Manhood Suffrage Association, had arranged an outdoor mass meeting. The Union passed a resolution wishing the League success and calling on

1 Cole and Filson, p. 529.

2 M.G., April I, I 864 .

3 Ibid., September 24, 1866. 
its own branches to aid in the meeting. It advertised in the newspapers for men to carry Union banners at the demonstration. The Manchester Guardian complained that "a looker-on who was unaware of the real fact might have been led to suppose that the whole meeting emanated from Newall's Buildings." At the principal platform (there were six in all) the leading middle-class Radicals were very much in evidence. The first resolution called for registered residential manhood suffrage. Another expressed "confidence in the honesty and ability of Mr. John Bright to champion the people's cause in Parliament during the coming parliamentary struggle." That evening the League participated in a meeting convened by the Reform Union. ${ }^{1}$

The same pattern appeared in other industrial towns: the outdoor mass meeting, preceded by processions of workingmen carefully organized by marshals; separate platforms for the sub-divisions of the main meeting; middle-class Radicals in attendance; then an evening meeting indoors, joined in by the leaders of official Liberalism. ${ }^{2}$ Throughout the country, with only minor variations, the middle-class Radicals collaborated with the working classes in a vast campaign for parliamentary reform. ${ }^{3}$

As a result of the initiative of the middle-class Radicals, the artisan classes were able to carry over into politics the role to which they had become so attached: co-operating with superiors in pursuit of objectives deemed appropriate to their station. The relationship between the Liberal workingman and his middle-class leaders was a satisfying one, because it was part and parcel of the way of life of the community as a whole. Lib-Labism, as it was later to be called, fitted neatly into the structure of Victorian urban culture. The Liberal affiliation of the artisan elite, rooted in the political and cultural circumstances of the mid-Victorian towns, was to exert a powerful stabilizing influence on late Victorian democracy.

Another element of stability in English democracy, the prestige of liberal ideology, also was significantly strengthened by the various

1 Ibid., September 25, 1866.

2 Reid, Life of Forster, I, pp. 392-6.

${ }^{3}$ On Tyneside a group of middle-class Radicals, led by Joseph Cowen, refused to stop short of manhood suffrage. In Birmingham the household suffrage position won a more complete triumph among both the middle and working classes, whereas another Midland town, Leicester, approximated the Lancashire and Yorkshire pattern, in that a substantial segment of the middle class held aloof from the Radicals. Such diversity, while of considerable importance, should not be permitted to obscure the unity of middle-class Radicalism in the industrial towns. See E. R. Jones, The Life and Speeches of Joseph Cowen, M.P.; R. A. McKinley ed., A History of the County of Leicester, IV, (London I958), pp. 216-24; and my article, The Origins of the Birmingham Caucus, in: Historical Journal, II, No. 2 (1959). 
campaigns for parliamentary reform. The traditional liberal premises - harmony of interests between the classes, the efficacy of reason in politics, and the possibility of progress through rational reform constituted the sort of optimistic assumptions that were well suited to smoothing the gears of newly democratized constitutional machinery. The parliamentary reform movement helped to impress a liberal form on the political consciousness of the working classes, particularly the aristocracy of labor.

By advocating the enfranchisement of urban householders the Radicals offered convincing proof of their own belief in the harmony of interests between the middle and working classes. Given this fundamental harmony, there was no reason why the classes could not overcome superficial differences and join together in the pursuit of progress. W. E. Forster was articulating a major theme of Radical oratory when he said: "Let us, then, all join together in this great and good work of turning these aliens into citizens; let capitalists and labourers, employers and employed, throw away their jealousies and suspicions and help in this work. I fully believe that, in as far as they perform it, they will find their reward in discovering that even those jealousies and suspicions will melt away and cease to exist." 1 Paradoxically, attacks on the aristocracy enhanced the class harmony theme by creating an image of the middle and working classes united in common devotion to reform in the face of benighted opposition by the landed oligarchy. The Radicals were fond of appealing to "the people" in this fashion: "Once let it be known that capital and labour were united, and the battle would be won peaceably. It would then be impossible that a great people should be over-ridden by an aristocracy too arrogant to be generous and too selfish to be just." 2 This speaker, like Bright, was certainly guilty of "fostering animosities of class". Nevertheless, in fostering a rather harmless and anachronistic animosity between aristocracy and "people", the Radicals were softening a far more dangerous class antagonism between bourgeoisie and proletariat.

Belief in the absence of fundamental conflict between the middle and working classes tended to reinforce the rationalism that constituted a second prominent feature of liberal ideology. Since the classes were not divided by conflicting interests, it was easy to accept the traditional liberal assumption that every problem has a rational solution, which, when discovered, will command the assent of men of reason and good will. In this vein the Radicals extolled the intelligence of the working-

1 Reid, Life of Forster, I, p. 399.

2 M.G., November 20, 1866. 
men they could be trusted to accept a "sound" policy when it was men as evidence of their fitness for enfranchisement. As intelligent presented to them. A classic expression of liberal confidence in the role of reason in politics occurs in a manifesto by the workingmen of the Reform League: "When our opponents see us determined, persevering and united, they will no longer refuse our just demands. They are our countrymen, and time and reflexion will lead them to act justly toward us." 1 Attitudes of this sort received powerful confirmation in the soothing reasonableness of the middle-class Radicals' arguments, especially on the ticklish subject of manhood versus household suffrage.

Belief in progress through rational reform constituted a third component of the liberal creed. Every aspect of the campaign for an extension of the franchise drove home the same point: just as the constitution could be reformed by organized persuasion, so other grievances would be removed in the onward march of reform. The Act of 1867 provided forceful proof of the validity of this expectation. The same procedure might be repeated indefinitely with similarly beneficial results.

The parliamentary reform agitation did not impose a factitious ideology of the twentieth century type; it strengthened and confirmed political beliefs that expressed the deepest values of the culture. In this well integrated culture there was a close correspondence between political and social values. Belief in progress through rational reform was the political correlative of the faith in individual improvement through intelligence and hard work. Liberal confidence in class harmony reflected the cultural preoccupation with smoothing class relations. Both in politics and in social life there was the same tendency to describe goals in moral and idealistic terms. In both spheres to be reasonable meant accepting the arguments of social superiors. Liberalism was not a narrowly political doctrine, but an expression of the mid-Victorian ethos. As such it was extremely effective in attenuating conflict and fostering co-operation after 1867 .

In this context the parliamentary reform meetings appear not merely as political gatherings, but as a crowning ritual of mid-Victorian urban culture, in which the middle and working classes acted out their prescribed roles and confirmed their common faith. The meetings manifested in visible form the class harmony that was acclaimed in oratory. Middle-class Radicals, actuated by reason and good will, demanded justice for the working classes and progress for the nation. Responsible workingmen, dutifully accepting their station in life,

${ }^{1}$ Cole and Filson, p. 535. 
welcomed the initiative of their superiors in an enterprise sanctioned by the highest moral and rational principles. Thus the classes gathered together in celebration of a liberal faith that united them morally without disturbing their social separateness. The proceedings corresponded closely to the standardized mid-Victorian ritual of tea parties, soirees, and official dedications. Utilizing familiar ceremonial forms, the reform meetings dramatized the terms on which the middle and working classes of the industrial towns had tacitly agreed to conduct their political relations.

By $x 867$, then, there had grown into being in the industrial towns political attitudes and habits that enabled England to embark on her experiment in democratic government under conditions conducive to the maximum stability. Working-class acceptance of middle-class leadership and ideology made certain that the newly democratized House of Commons would not have to deal with any really awkward economic and social questions. England's inchoate democracy was spared the strain that would have been caused by the demands of a less acquiescent working class.

The manner in which the industrial towns dealt with the franchise issue in the 1850's and 1860's also contributed to the profoundly conservative character of English politics in the last third of the nineteenth century. Old habits of deference and subordination, rooted in an inegalitarian society and reinforced by the agitation for parliamentary reform, persisted after i 867 . In contrast to the situation in France and Germany, where strong socialist parties emerged at an early date, the English working classes were content with the Liberals and the Conservatives. H. J. Hanham's study has shown the extent to which working-class voters responded to the electoral influence wielded by industrial magnates in behalf of the traditional parties. ${ }^{1}$ The majority of employers "simply expected some deference to their wishes because they thought it natural that workingmen should look to their 'betters' for guidance." 2 Such deference continued to be forthcoming for some time.

The most strikingly conservative characteristic of English democracy in the last third of the nineteenth century - the staunch loyalty of the working-class elite to Liberalism and the Liberal Party - also had its origin in the mid-Victorian towns. The basic components of LibLabism had been forged in the 1850 's and 1860 's; their future development was to be determined by Liberal policy. In I 868 the Liberal

1 H. J. Hanham, Elections and Party Management: Politics in the Time of Disraeli and Gladstone (London 1959), pp. 68-90.

2 Ibid., p. 8 I. 
Whips exploited to the utmost their advantageous position when they made an agreement with George Howell of the Reform League that prevented independent working-class activity in the general election and made the League itself an electoral instrument of the Liberal party. ${ }^{1}$ Lib-Labism was even strong enough to survive Gladstone's labor policy, and in the $1870^{\circ}$ 's local workingmen's clubs and associations gravitated into the orbit of the Liberal party. ${ }^{2}$ Trade union

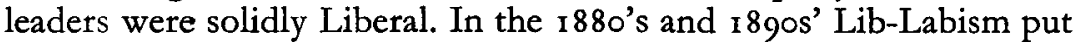
up a strong fight against socialist efforts to establish an independent labor party. Even at the end of the nineteenth century "the great majority of trade-union leaders were members of the Liberal Party, and Gladstonians at that." 3 Only reluctantly, when local Liberal associations insisted on nominating middle-class candidates, did the working-class elite abandon their allegiance to the party of Gladstone and Bright. ${ }^{4}$

Thus, the mid-Victorian towns were of strategic importance in the social and political development of modern England because of their success in solving the difficult problems in class relations inherited from the Chartist era. In politics the middle and working classes found a solution that combined a fairly considerable extension of the franchise with political and ideological forms congenial to an inegalitarian society. On the basis of this settlement in the towns, England moved cautiously in the direction of democracy.

\footnotetext{
1 Royden Harrison, The British Working Class and the General Election of 1868 , in: International Review of Social History, vol. V (1960), part 3, and vol. VI (196r), part 1. Harrison has shown the importance of Liberal money in inducing Howell to enter into these Lib-Lab arrangements, which did not spring spontaneously from the Liberal inclinations of the working-class leadership. On the other hand, the deal with Howell would not have worked had not the vast majority of the artisan class been very favorably disposed to the Liberal party.

2 G. D. H. Cole, British Working Class Politics r832-1914 (London 194r), pp. 52-76; Hanham, chapters 7 and $15 ; \mathrm{H}$. Pelling, The Origins of the Labour Party 1880-1900 (London 1954), pp. 3-8.

${ }^{3}$ Pelling, p. 218.

4 Ibid., pp. $235-8$.
} 